\title{
Renal effects of uric acid: hyperuricemia and hypouricemia
}

\author{
Jung Hwan Park, Young-Il Jo, and Jong-Ho Lee
}

Division of Nephrology, Department of Internal Medicine, Konkuk University School of Medicine, Seoul, Korea

\section{Received: August 10, 2020}

Accepted: August 31, 2020

\section{Correspondence to}

Jung Hwan Park, M.D.

Division of Nephrology,

Department of Internal

Medicine, Konkuk University

Medical Center, 120-1

Neungdong-ro, Gwangjin-gu,

Seoul 05030, Korea

Tel: +82-2-2030-7528,

Fax: +82-2-2030-7748,

E-mail: pjh@kuh.ac.kr

https://orcid.org/0000-0002-8737-

0084

This paper was contributed by The Korean Society of Nephrology.
The prevalence of chronic kidney disease (CKD) is increasing worldwide. Although hyperuricemia has been associated with CKD in many studies, it remains controversial whether this is the cause or the result of decreased renal function. Recent observational studies of healthy populations and patients with CKD have reported that uric acid (UA) has an independent role in the development or progression of CKD. Experimental studies have shown several potential mechanisms by which hyperuricemia may cause or promote CKD. However, other reports have indicated an association between hypouricemia and CKD. This opposing effect is hypothesized to occur because UA is a major antioxidant in human plasma and is associated with oxidative stress. In this article, we discuss the potential association between UA imbalance and CKD and how they can be treated.

Keywords: Uric acid; Hyperuricemia; Hypouricemia; Kidney

\section{INTRODUCTION}

Chronic kidney disease (CKD) is a significant public health issue globally, with an estimated prevalence of 7.9\% in Korea [1]. The number of patients undergoing dialysis in Korea has continued to increase due to worsening kidney function in patients with CKD [2]. CKD is not only associated with developing end-stage renal disease (ESRD) but also with an increased risk of cardiovascular disease (CVD) [3]. Indeed, the hypothesis that uric acid (UA) could mediate CVD or hypertension was proposed nearly 140 years ago [4]. In 1889, it was proposed that UA mediated diseases, such as CKD, hypertension, and diabetes [5], and in 1897 , hyperurice- mia and gout were reported to be associated with renal dysfunction [6]. According to data collected when no drugs were available to reduce serum UA levels, proteinuria was common (occurring in $25 \%$ of cases) in patients with gout, renal function frequently decreased (50\% of cases), and ESRD occurred in $10 \%$ to $25 \%[7,8]$. Although evidence shows that UA is associated with the development of CKD, controversy remains as to whether this is the cause or the result of decreased renal function $[9,10]$. Most studies have shown a relationship between CKD and hyperuricemia, but some have also shown an association between decreased renal function and hypouricemia $[11,12]$. 


\section{URIC ACID METABOLISM}

UA is generated in the liver from the catabolism of exogenous and endogenous purine mononucleotides into hypoxanthine and guanine [13]. Hypoxanthine is further oxidized by xanthine dehydrogenase/oxidase to form xanthine, which is further oxidized by the same enzyme to form UA. This constitutes the end product of purine nucleotide metabolism in higher primates [14]. In other mammals, UA is further degraded by uricase, an enzyme that primates lack, to become allantoin [15], which is more water-soluble than UA and can be efficiently excreted in urine [16]. Mammals with the uricase enzyme usually show lower UA levels (1 to $2 \mathrm{mg} / \mathrm{dL}$ ), whereas primates have UA levels that are 3- to 10-times higher [17].

In humans, approximately two-thirds of all UA is excreted in the urine, and one-third is excreted in the gastrointestinal tract [18]. UA is filtered by the glomeruli and reabsorbed by the proximal tubule with a normal fractional excretion of $10 \%$ [13]. Urate transporter 1 (URAT1; SLC22A12) reabsorbs glomerular-filtrated UA and is localized on the luminal side of proximal tubule cells [19], while glucose transporter 9 (GLUT9; SLC2A9) allows intracellular UA to exit through the basolateral side of the cells (Table 1) [18,20]. Otherwise, UA secretion is mediated by ATP-binding cassette transporter subfamily G member 2 (ABCG2) and sodium-dependent phosphate transporter 1 (NPT1; SLC1JA1) and 4 (NPT4;
SLC17A3) [21-23]. Studies of polymorphisms in these transporters suggest that renal overload hyperuricemia is a novel pathophysiological mechanism in gout [24]. However, in an experimental study of 5/6 nephrectomized rats, the expression levels of URAT1, GLUT 9 , $\mathrm{ABCG}_{2}$, and $\mathrm{NPT}_{4}$ in the proximal tubules decreased, which may have been associated with CKD-related tubular injury [25]. This suggests that tubular urate transporters do not cause hyperuricemia directly; instead, this results from a decrease in UA filtered by the glomeruli [26].

\section{Mechanisms of hyperuricemia}

Hyperuricemia has been defined as $\geq 7.0 \mathrm{mg} / \mathrm{dL}$ in men, and $\geq 5.7[27]$ or $\geq 6 \mathrm{mg} / \mathrm{dL}$ [28] in women. Although hyperuricemia occurs in patients with CKD, the fact that hyperuricemia can precede CKD suggests that other factors are relevant. Risk factors for CKD include metabolic syndrome, which is associated with hyperuricemia [29], insulin resistance and hyperinsulinemia, which reduce urinary UA excretion [30], and hypertension, which increases renal vascular resistance and UA retention [31]. However, recent studies have shown that hyperuricemia, i.e., increased serum UA levels, may prevail in these conditions and occur earlier, indicating that other factors may be the underlying cause of hyperuricemia [32,33]. For example, diets high in meat, seafood, sugar, and beer are all associated with an increased risk of hyper-

Table 1. Renal urate transporters and associated conditions

\begin{tabular}{|c|c|c|c|c|}
\hline Transporter & Gene & Location & Function & $\begin{array}{l}\text { Gene mutation } \\
\text { result }\end{array}$ \\
\hline $\begin{array}{l}\text { Urate transporter } 1 \\
\text { (URAT1) }\end{array}$ & $\mathrm{SLC22A12}$ & $\begin{array}{l}\text { Luminal membrane of } \\
\text { proximal renal tubule }\end{array}$ & $\begin{array}{l}\text { Reabsorbs glomerular-filtrated } \\
\text { UA }\end{array}$ & Hypouricemia \\
\hline $\begin{array}{l}\text { Glucose transporter } 9 \\
\left(\text { GLUT }_{9}\right)\end{array}$ & $\mathrm{SLC}_{2} \mathrm{~A}_{9}$ & $\begin{array}{l}\text { Basolateral membrane of } \\
\text { proximal renal tubule }\end{array}$ & $\begin{array}{l}\text { Allows intracellular UA to exit } \\
\text { through the basolateral side of } \\
\text { the cells }\end{array}$ & Hypouricemia \\
\hline $\begin{array}{l}\text { ATP-binding cassette } \\
\text { transporter subfamily G } \\
\text { member } 2(\mathrm{ABCG} 2)\end{array}$ & $\mathrm{ABCG} 2$ & $\begin{array}{l}\text { Luminal membrane of } \\
\text { proximal renal tubule }\end{array}$ & UA excretion & Hyperuricemia \\
\hline $\begin{array}{l}\text { Sodium-dependent } \\
\text { phosphate transporter } 1 \\
\text { (NPT1) }\end{array}$ & $\mathrm{SLC} 17 \mathrm{~A} 1$ & $\begin{array}{l}\text { Luminal membrane of } \\
\text { proximal renal tubule }\end{array}$ & UA excretion & Hyperuricemia \\
\hline $\mathrm{NPT}_{4}$ & $\mathrm{SLC}_{17} \mathrm{~A}_{3}$ & $\begin{array}{l}\text { Luminal membrane of } \\
\text { proximal renal tubule }\end{array}$ & UA excretion & Hyperuricemia \\
\hline
\end{tabular}

UA, uric acid. 
uricemia, whereas diets rich in dairy products are associated with a decreased risk [34]. Children with a history of low birth weight also show increased serum UA levels, endothelial dysfunction, and hypertension [35]. Finally, genetic factors are also involved. Familial juvenile hyperuricemic nephropathy is a rare autosomal dominant disease that results from a mutation in the uromodulin gene. It is characterized by abnormal handling of UA and hyperuricemia, and it is often complicated by gouty arthritis, with renal failure occurring due to tubulointerstitial nephritis [36]. In some studies, plasma volume contraction and compensatory higher reabsorption activity of the proximal tubule including upregulation of $\mathrm{Na}^{+}$-coupled urate transporters was suggested to be the cause of the hyperuricemia in cases of the uromodulin gene mutation [37,38]. A genome-wide association study of gout and its subtypes was performed to identify novel gout loci [39].

\section{Mechanisms of hypouricemia}

Hypouricemia is defined as a serum UA of $\leq 2.0 \mathrm{mg} / \mathrm{dL}$ [40]. In a Japanese population, it was reported to occur in 193 of 90,710 men (0.2\%) and 540 of 136,935 women (0.4\%) [11], while in Korea, the prevalence has been reported to be $4.14 \%(299 / 7,223)$ among inpatients and $0.53 \%$ $(125 / 23,534)$ among outpatients, with an overall prevalence of $1.39 \%(424 / 30,757)$ [41]. Hypouricemia can be divided into conditions that result from decreased UA production and those that result from increased renal clearance.

Hereditary xanthinuria is an autosomal recessive disease caused by a deficiency of the xanthine dehydrogenase/oxidase enzyme that results in decreased UA production. This disorder is marked by hypouricemia, low urinary concentrations of urate, and high urinary concentrations of xanthine, which lead to the development of urinary xanthine kidney stones [42].

Urate-lowering drugs, such as allopurinol and febuxostat, inhibit xanthine oxidase, and cause hypouricemia. Pegloticase, a mammalian recombinant pegylated uricase enzyme that converts urate into allantoin has 5 to 10-fold increased solubility. When used as indicated to treat severe refractory gout it converts urate into the more soluble allantoin that is more readily excreted by the kidney. Using pegloticase can cause severe hypouricemia with UA levels falling below $2 \mathrm{mg} / \mathrm{dL}$ in some patients $[43,44]$. Several other uricosuric agents also de- crease serum UA levels [45]. These include probenecid, benzbromarone, angiotensin II receptor blockers, fenofibrate, trimethoprim-sulfamethoxazole, and high-dose salicylate [46-48].

Gene mutations can also cause renal hypouricemia, such as those of SLC22A12, encoding URAT1 [49-53], and SLC2A9, encoding GLUT9 [54,55]. Most patients are asymptomatic, but some may be predisposed to urinary tract stones or exercise-induced acute renal failure [56]. In the latter case, patients will show a high fractional excretion of $\mathrm{UA}(>10 \%)$.

Hypouricemia has also been reported in patients with diabetes [57,58], where it is known to occur due to increased renal excretion and only in patients with normal renal function $[59,60]$. Low levels of serum UA may also develop secondary to expansion of extracellular volume, which reduces proximal reabsorption of sodium and UA [61]. This is common when patients receive large volumes of intravenous fluid or when patients have psychogenic polydipsia or syndrome of inappropriate antidiuretic hormone. Several hepatic diseases, such as cholangiocarcinoma, viral hepatitis, and primary biliary cirrhosis, have been associated with hypouricemia due to abnormal UA reabsorption [62-64]. Patients with Hodgkin's disease may also develop marked hypouricemia because of an isolated defect in urate reabsorption [65], though successful treatment of the underlying disease appears to correct this abnormal renal handling of urate.

\section{PATHOPHYSIOLOGY OF URIC ACID-RELATED KIDNEY DISEASE}

\section{Hyperuricemia and kidney}

Kidney damage due to hyperuricemia has traditionally been thought to result from the effect of UA crystals [66]. Hyperuricemia associated with hyperuricosuria (urinary UA excretion $>800 \mathrm{mg} /$ day in men and $>750 \mathrm{mg} /$ day in women) has been postulated to cause acute kidney damage by depositing crystals intraluminally in the collecting ducts. In turn, this causes tubular obstruction, the development of an inflammatory response, and progressive tubulointerstitial damage over time that lowers the estimated glomerular filtration rate (eGFR). Multiple crystal-independent mechanisms have been sug- 
gested in basic research, including renal vasoconstriction mediated by endothelial dysfunction, activation of the renin-angiotensin system, afferent arteriolopathy, and the epithelial-to-mesenchymal transition in renal tubular cells [67-72].

It is assumed that UA acts as a powerful antioxidant in the extracellular environment, but that it is a prooxidant inside the cell, where it stimulates nicotinamide adenine dinucleotide phosphate (NADPH) oxidase [72]. UA has been reported to induce endothelial dysfunction by increasing oxidative stress and decreasing the bioavailability of endothelial nitric oxide [73]. Some research suggests that lowering UA with allopurinol may improve endothelial dysfunction in humans [74,75].

In animal models, hyperuricemia increases cyclooxygenase-2 expression and leads to the proliferation of vascular smooth muscle cells in preglomerular arterioles [7o]. Hyperuricemia in rats induces hypertension, renal injury, and fibrosis, in part by activating the renin-angiotensin system [67]. Preglomerular vasculopathy caused by hyperuricemia deranges the autoregulatory response of afferent arterioles and triggers glomerular hypertension $[69,76]$. In addition, lumen obliteration induced by vascular wall thickening results in severe vasoconstriction that decreases renal blood flow, the eGFR, and perfusion to peritubular capillaries, causing tubulointerstitial inflammation, tubulointerstitial fibrosis, and arterial hypertension [71]. UA induces tubulointerstitial fibrosis via the epithelial-to-mesenchymal transition in renal tubular cells [77].

\section{Hypouricemia and kidney}

UA is an important antioxidant in human plasma and, as such, hypouricemia has been proposed to increase the risk of a decline in kidney function by reducing antioxidant capacity [78-80]. Consistent with this, hypouricemia has been associated with several inflammatory and degenerative diseases, including acute graft-versushost disease, Alzheimer's disease, Huntington's disease, Parkinson's disease, and multiple sclerosis [81,82]. These associations have been attributed to reduced antioxidative capacity $[81,82]$.

Hypouricemia has also been associated with urolithiasis and exercise-induced acute kidney injury (EIAKI), particularly in patients with hereditary hypouricemia $[83,84]$. Because UA acts as an antioxidant that pro- tects endothelial function, hypouricemia causes EIAKI through renal artery spasm, with a clinical picture that is characterized by nausea, vomiting, and loin, and abdominal pain. In a Japanese study, all patients with EIAKI later recovered their kidney function, but $24 \%$ experienced recurrent acute kidney injury (AKI) [85]. Pathology revealed chronic lesions, such as thickening of the tubular basement membrane and interstitial fibrosis, despite a normal creatinine clearance rate in some patients who experienced recurrent AKI. Although the loss to follow-up meant that the researchers did not report if these patients developed CKD, it is certainly plausible that recurrent AKI can lead to CKD [86]. In addition, excessive urinary excretion of UA can result in the formation of UA crystals, causing urolithiasis in patients with hypouricemia [87]. Urolithiasis and EIAKI have a prevalence of $8.5 \%$ and $6.5 \%$, respectively, in patients with hereditary renal hypouricemia based on genetic testing [51].

\section{RELATIONSHIP BETWEEN URIC ACID AND CKD PROGRESSION: OBSERVATIONAL STUDIES}

\section{Hyperuricemia and CKD}

Many large observational studies have examined the association between serum UA and the development or progression of CKD in both the general population and in patients with existing CKD (Table 2) [88-99]. Most observational studies have shown positive results, with hyperuricemia being an independent risk factor for the development and progression of kidney disease in diabetic or non-diabetic patients [88-95,99,100]. In a meta-analysis involving 13 observational trials of 190,718 patients with normal renal function, hyperuricemia was an independent risk factor for developing CKD [100]. The summary odds ratio (OR) for the association between hyperuricemia and developing new-onset CKD increased with increasing follow-up, indicating that hyperuricemia may play a role in the long-term progression of renal function. A subgroup analysis revealed a stronger association between hyperuricemia and CKD development in Western than in Asian populations. This difference may result from racial, geographic, or dietary differences because the Western diet possibly contains more purine-rich foods. 
Table 2. Observational studies of hyperuricemia and CKD

\begin{tabular}{|c|c|c|c|c|}
\hline Country & Population & Design (follow-up yr) & Finding & Study \\
\hline Japan & 6,403 Adults, healthy & Prospective cohort (6.75) & $\begin{array}{l}\text { SUA >6.o mg/dL was an independent } \\
\text { predictor of ESRD in women }(\mathrm{HR}, \\
5.77)\end{array}$ & Iseki et al. (2004) [99] \\
\hline Thailand & 3,499 Adults, healthy & Prospective cohort (12) & $\begin{array}{l}\text { SUA }>6.3 \mathrm{mg} / \mathrm{dL} \text { associated with risk } \\
\text { of development of decreased kidney } \\
\text { function }(\mathrm{OR}, 1.82)\end{array}$ & $\begin{array}{l}\text { Domrongkitchaiporn et } \\
\text { al. (2005) [90] }\end{array}$ \\
\hline USA & 5,808 Adults, healthy & Prospective cohort (6.9) & $\begin{array}{l}\text { SUA was strongly associated } \\
\text { with prevalence but weakly with } \\
\text { progression of CKD }(\mathrm{OR}, 1.49)\end{array}$ & Chonchol et al. (2007) [91] \\
\hline Austria & 21,457 Adults, healthy & Prospective cohort (7) & $\begin{array}{l}\text { SUA }>7 \mathrm{mg} / \mathrm{dL} \text { increased CKD risk } \\
(\mathrm{OR}, 1.74),>9.0 \mathrm{mg} / \mathrm{dL}(\mathrm{OR}, 3.12)\end{array}$ & $\begin{array}{l}\text { Obermayr et al. (2008) } \\
{[92]}\end{array}$ \\
\hline USA & 675 Type 1 DM & Cross-sectional & $\begin{array}{l}\text { SUA in the high-normal range is } \\
\text { associated with impaired renal } \\
\text { function }\end{array}$ & $\begin{array}{l}\text { Rosolowsky et al. (2008) } \\
\text { [88] }\end{array}$ \\
\hline USA & 177,570 Adults, healthy & Prospective cohort (25.7) & $\begin{array}{l}\text { Higher quartile of SUA conferred } \\
2.14 \text {-fold increased risk of ESRD }\end{array}$ & Hsu et al. (2009) [93] \\
\hline Italy & 900 Adults, healthy & Prospective cohort (5) & $\begin{array}{l}\text { Each } 1 \mathrm{mg} / \mathrm{dL} \text { increase in SUA } \\
\text { increased risk of reduced eGFR } \\
(\mathrm{HR}, 1.28)\end{array}$ & Bellomo et al. (2010) [94] \\
\hline Japan & 7,078 Adults, healthy & Prospective cohort (5) & $\begin{array}{l}\text { SUA level is an independent } \\
\text { predictor of CKD onset (OR, 1.15) }\end{array}$ & Sonoda et al. (2011) [95] \\
\hline Italy & 1,449 Type 2 DM & Prospective cohort (5) & $\begin{array}{l}\text { 1-SD increment in SUA was } \\
\text { associated with a } 21 \% \text { increased risk } \\
\text { of CKD. }\end{array}$ & Zoppini et al. (2012) [89] \\
\hline Japan & $\begin{array}{l}\text { 803 Adults, CKD stage } \\
3-4\end{array}$ & $\begin{array}{l}\text { Retrospective cohort }(4) \\
\text { Propensity score } \\
\text { analysis }\end{array}$ & $\begin{array}{l}\text { UA }>6.5 \mathrm{mg} / \mathrm{dL} \text { increased ESRD risk } \\
(\mathrm{HR}, 2.39)\end{array}$ & Uchida et al. (2015) [96] \\
\hline USA & $\begin{array}{l}\text { 627 Children, CKD } \\
\text { (median GFR } \\
58.1 \mathrm{~mL} / \mathrm{min} / 1.73 \mathrm{~m}^{2} \text { ) }\end{array}$ & Prospective cohort (5) & $\begin{array}{l}\text { SUA }>7.5 \mathrm{mg} / \mathrm{dL} \text { is an independent } \\
\text { risk factor for faster progression of } \\
\text { CKD in children and adolescents }\end{array}$ & $\begin{array}{l}\text { Rodenbach et al. (2015) } \\
\text { [97] }\end{array}$ \\
\hline Korea & $\begin{array}{l}\text { 2,042 Adults, CKD } \\
\text { stage } 1-5\end{array}$ & $\begin{array}{l}\text { Prospective cohort } \\
(2.12)\end{array}$ & $\begin{array}{l}\text { Each } 1 \mathrm{mg} / \mathrm{dL} \text { increase in SUA in- } \\
\text { creased the risk of progression to } \\
\text { renal failure (HR, 1.277) }\end{array}$ & Oh et al. (2019) [98] \\
\hline
\end{tabular}

CKD, chronic kidney disease; SUA, serum uric acid; ESRD, end-stage renal disease; HR, hazard ratio; OR, odds ratio; DM, diabetes mellitus; eGFR, estimated glomerular filtration rate; SD, standard deviation; UA, uric acid; GFR, glomerular filtration rate.

Serum UA in the high-normal range $(\leq 4.0 \mathrm{mg} / \mathrm{dL}$ vs. > $4.0 \mathrm{mg} / \mathrm{dL}$ ) is associated with impaired renal function in patients with type 1 diabetes [88]. In people with type 2 diabetes and preserved kidney function, hyperuricemia $(\geq 7.0 \mathrm{mg} / \mathrm{dL}$ in men and $\geq 6.5 \mathrm{mg} / \mathrm{dL}$ in women or those on allopurinol therapy) is an independent risk factor for incident cases of CKD [89]. In a Japanese screened cohort study, hyperuricemia (serum UA > 6.0 mg/dL) was an independent predictor of ESRD in women [99], but there was no significant association in men. A previous study in which ESRD was followed up for 25 years reported hyperuricemia as an independent risk factor for ESRD [93], and in a prospective follow-up study of 21,475 healthy participants, hyperuricemia independently increased the risk for new-onset kidney disease [92].

Understanding the role of UA in predicting the progression of kidney disease in patients with CKD is more controversial due to the unavoidable causal relationship. 
Uchida et al. [96] used a propensity score analysis to clarify the independent effect of UA on the subsequent risk of ESRD. They showed that higher serum UA accelerated the progression to subsequent ESRD in a retrospective CKD cohort. In another study of children and adolescents with a median age of 12.3 years, hyperuricemia was an independent risk factor for faster CKD progression [97]. In a Korean cohort study of patients with CKD and a mean eGFR of $52.80 \pm 12.3 \mathrm{~mL} / \mathrm{min} / 1.73 \mathrm{~m}^{2}$, the risk of progression to renal failure increased by $28 \%$ (hazard ratio [HR], 1.277; 95\% confidence interval [CI], 1.212 to 1.345) for each $1 \mathrm{mg} / \mathrm{dL}$ increase in the baseline UA level [98]. Multivariate analysis found an association between the upper UA quartile and an increased risk of composite renal outcome (HR, 3.590; 95\% CI, 2.546 to 5.063). Hyperuricemia was associated with the development of CKD in a risk score model $[101,102]$. Hyperuricemia is associated with sarcopenia, and sarcopenia is associated with CKD progression, death, and CVD in CKD patients [103,104]. Fat accumulation in and around the kidneys is associated with hyperuricemia and the development of CKD $[105,106]$.

Other observational studies have failed to show a significant relationship between hyperuricemia and the progression of CKD [107,108]. In a study of patients with mild-to-moderate CKD and no diabetes, increasing serum UA levels predicted disease progression only when the analysis was not adjusted for baseline kidney function parameters. After adjusting for baseline eGFR and proteinuria, the association completely vanished [107]. Similarly, a analysis of the Modification of Diet in Renal Disease study, which enrolled 838 patients with stage 3 to 4 CKD, showed that hyperuricemia was an independent risk factor for all-cause and CVD mortality, but not kidney failure [108]. Serum UA levels of 3,885 patients with stage 2 to 4 CKD in the Chronic Renal Insufficiency Cohort were examined, and serum UA levels were reported to be an independent risk factor for progression to dialysis or transplantation when the initial eGFR was $>45 \mathrm{~mL} / \mathrm{min} / 1.73 \mathrm{~m}^{2}$ but not when it was $<30$ $\mathrm{mL} / \mathrm{min} / 1.73 \mathrm{~m}^{2}[109]$. The authors postulated that higher UA levels at preserved eGFRs have more relevance for kidney failure than at lower GFRs. When GFR is preserved, the deleterious effects of UA may therefore be more pathogenic and easier to discern than when kidney function is worse, at which point factors that govern the increase in UA levels and increased morbidity may be more important.

\section{Hypouricemia and CKD}

A U-shaped association has been reported between serum UA level and CVD mortality, suggesting that both hyperuricemia and hypouricemia are risk factors for CVD mortality [110,111]. However, there are few reports of this association between serum UA and the loss of kidney function.

In a Japanese prospective cohort study among healthy people, both decreased and increased serum UA levels were associated with a loss of kidney function [112]. The study population comprised 104,796 asymptomatic people. Of the 9,847 without CKD, 4,188 were followed up for at least 3 years, 3,102 for 6 years, and 1,052 for 9 years. Overall, the mean serum UA level was $5.8 \pm 1.2 \mathrm{mg} / \mathrm{dL}$ in men and $4.1 \pm 0.9 \mathrm{mg} / \mathrm{dL}$ in women. Many men had incident CKD and a > 25\% decrease in eGFR in groups 4 (serum $U A \geq 6.5 \mathrm{mg} / \mathrm{dL}$ ) and 1 (serum $\mathrm{UA} \leq 5.0 \mathrm{mg} /$ $\mathrm{dL})$, respectively. In subjects with low serum UA levels (men, < $5 \mathrm{mg} / \mathrm{dL}$; women, $<3.6 \mathrm{mg} / \mathrm{dL}$ ), multivariate linear mixed models showed a time-dependent association with declining eGFR. Logistic additive models also showed that both high and low serum UA levels affected the likelihood of the outcome events more than intermediate levels among men, but not among women.

In a population-based cross-sectional study, hypouricemia (serum $U A \leq 2 \mathrm{mg} / \mathrm{dL}$ ) was associated with reduced kidney function in men (OR, 1.83; 95\% CI, 1.23 to 2.74), but not in women (OR, 0.61; 95\% CI, 0.43 to 0.86 ), when compared against a reference category (serum UA levels of 4.1 to $5.0 \mathrm{mg} / \mathrm{dL}$ ) and after adjusting for age, drinking, smoking, diabetes, hypertension, hypercholesterolemia, obesity, and history of renal failure [11]. In another Japanese cross-sectional study in the general population, the rates of previous urinary stones and kidney diseases (including nephritis/nephrosis) were 1.2\% (3.3\% men, 0.7\% women) and $2.3 \%$ (10\% men, $0.7 \%$ women), respectively. Men with hypouricemia had a 9-fold higher rate of previous kidney diseases compared with those who had no hypouricemia [113].

Finally, a Korean prospective cohort study in a rural population revealed that both high and low serum UA levels were risk factors for the development of CKD in men, but that only high levels were a risk factor in wom- 
Table 3. Clinical trials of UA-lowering therapy on CKD

\begin{tabular}{|c|c|c|c|c|}
\hline Country & Population (follow-up yr) & Drug, dosing per day & Finding & Study \\
\hline China & $\begin{array}{l}54 \mathrm{CKD} ; \text { serum creatinine } \\
1.35-4.5 \mathrm{mg} / \mathrm{dL}(\mathrm{l})\end{array}$ & Allopurinol, 100-300 mg & $\begin{array}{l}\text { Allopurinol helps preserve kidney } \\
\text { function during } 12 \text { months of therapy } \\
\text { compared with controls }\end{array}$ & $\begin{array}{l}\text { Siu et al. } \\
(2006)[117]\end{array}$ \\
\hline Spain & $113 \mathrm{CKD}_{3}(2)$ & Allopurinol, $100 \mathrm{mg}$ & $\begin{array}{l}\text { Slows down the progression of renal } \\
\text { disease }\end{array}$ & $\begin{array}{l}\text { Goicoechea et al. } \\
(2010)[118]\end{array}$ \\
\hline Iran & $\begin{array}{l}\text { 40 type } 2 \mathrm{DM} \text {; serum } \\
\text { creatinine }<3.0 \mathrm{mg} / \mathrm{dL} \\
\text { ( } 4 \text { months) }\end{array}$ & Allopurinol, $100 \mathrm{mg}$ & $\begin{array}{l}\text { Reduced proteinuria, no difference in } \\
\text { serum creatinine }\end{array}$ & $\begin{array}{l}\text { Momeni et al. } \\
(2010)[119]\end{array}$ \\
\hline China & $\begin{array}{l}40 \text { IgA nephropathy; serum } \\
\text { creatinine }<3 \mathrm{mg} / \mathrm{dL}(0.5)\end{array}$ & Allopurinol, 100-300 mg & No difference was found in eGFR & $\begin{array}{l}\text { Shi et al. } \\
(2012)[120]\end{array}$ \\
\hline India & $93 \mathrm{CKD}_{3}, 4(0.5)$ & Febuxostat, $40 \mathrm{mg}$ & $\begin{array}{l}\text { Slowed the decline in eGFR compared } \\
\text { to placebo }\end{array}$ & $\begin{array}{l}\text { Sircar et al. } \\
(2015)[121]\end{array}$ \\
\hline Japan & $467 \mathrm{CKD}_{3}(2)$ & Febuxostat, $20-40 \mathrm{mg}$ & $\begin{array}{l}\text { No significant difference in mean } \\
\text { eGFR slope }\end{array}$ & $\begin{array}{l}\text { Kimura et al. } \\
(2018)[122]\end{array}$ \\
\hline Korea & ${ }_{141} \mathrm{CKD}_{3}(5)$ & Febuxostat, 20-80 mg, & $\begin{array}{l}\text { Febuxostat reduced the risk of renal } \\
\text { disease progression compared to } \\
\text { control }\end{array}$ & $\begin{array}{l}\text { Lee et al. } \\
(2019)[123]\end{array}$ \\
\hline China & 152 CKD 2-3 (0.5) & $\begin{array}{l}\text { Febuxostat, } 20-40 \mathrm{mg} \\
\text { Allopurinol, } 100-200 \mathrm{mg}\end{array}$ & $\begin{array}{l}\text { Febuxostat, superior in delaying renal } \\
\text { impairment progression compared to } \\
\text { allopurinol }\end{array}$ & $\begin{array}{l}\text { Zhang et al. } \\
(2019)[124]\end{array}$ \\
\hline
\end{tabular}

UA, uric acid; CKD, chronic kidney disease; DM, diabetes mellitus; IgA, immunoglobulin A; eGFR, estimated glomerular filtration rate.

en [114]. Among the 5,577 participants, 9.4\% of men and $11.0 \%$ of women developed CKD. The HR for CKD was higher in the fourth quintile of serum UA levels than in the third quintile in men (adjusted HR, 1.60; 95\% CI, 1.02 to 2.51 ) and women (adjusted HR, 1.56; 95\% CI, 1.14 to 2.15). The development of CKD was also more common in the lowest quintile of serum UA levels than in the third quintile in men (adjusted HR, 1.83; 95\% CI, 1.15 to 2.90). Patients with ESRD and low serum UA levels were also reported to have a higher mortality risk than those with high serum UA levels [115].

\section{EFFECTS OF URIC ACID-LOWERING THERAPY ON CKD}

In a meta-analysis of 12 studies, Liu et al. [116] reported that UA-lowering therapy is associated with slowed CKD progression. The pooled estimate for eGFR favored UA-lowering therapy with a mean difference of $3.88 \mathrm{~mL} / \mathrm{min} / 1.73 \mathrm{~m}^{2}$ (95\% CI, 1.26 to 6.49 ). The risk of worsened kidney function, ESRD, or death decreased significantly in the treatment group compared with the control group (relative risk, $0.39 ; 95 \% \mathrm{CI}, 0.28$ to 0.52 ) [116]. Clinical trials of UA-lowering therapy published to date are listed in Table 3 [117-124]. In these studies, UA levels during treatment remained at 5 to $6 \mathrm{mg} / \mathrm{dL}$.

\section{Allopurinol}

Allopurinol is metabolized by xanthine oxidase to oxypurinol, which in turn, noncompetitively inhibits xanthine oxidase [13]. Allopurinol is usually started at 100 mg daily in patients with normal renal function and titrated every 2 to 4 weeks to the minimum dose required to achieve and maintain the goal range of serum UA. The half-lives of allopurinol and its active metabolite, oxypurinol, are prolonged in patients with renal dysfunction [125]. A daily starting dose of allopurinol of $<1.5 \mathrm{mg} / \mathrm{mL} /$ min of eGFR is advised in such patients, with dose increments of no more than $50 \mathrm{mg}$ daily every 4 weeks to the minimum daily dose necessary to achieve the goal $[126,127]$. Among relatively mild adverse reactions occur- 
ring in $3 \%$ to $5 \%$ of patients treated with allopurinol are rash, leukopenia or thrombocytopenia, and diarrhea. Severe reactions, such as severe cutaneous adverse reactions, may occur very rarely, but still occur in subjects with the human leukocyte antigen (HLA) B* 58:01 allele, $\mathrm{CKD}$, and use of a thiazide/loop diuretic [128,129].

Several studies have investigated the effect of allopurinol therapy on kidney outcomes $[117,118,120,130]$. Siu et al. [117] reported that it slowed renal disease progression in hyperuricemic subjects with mild-to-moderate CKD $(1.35<$ serum creatinine $\leq 4.50 \mathrm{mg} / \mathrm{dL})$ after 1 year. In a prospective controlled study, Goicoechea et al. [118] further reported that allopurinol preserved renal function. They randomly assigned patients with CKD either to receive allopurinol $100 \mathrm{mg} /$ day or to continue with their usual therapy. A decrease of the serum UA level from $7.8 \pm 2.1$ to $6.0 \pm 1.2 \mathrm{mg} / \mathrm{dL}$ was not associated with a significant change in the eGFR $(40.8 \pm 11.2$ to $42.2 \pm$ $13.2 \mathrm{~mL} / \mathrm{min} / 1.73 \mathrm{~m}^{2}$ ), whereas the eGFR fell in the control group ( $39.5 \pm 12.4$ to $35.9 \pm 12.3 \mathrm{~mL} / \mathrm{min} / 1.73 \mathrm{~m}^{2}$ ). Allopurinol treatment was also associated with fewer CVD events (seven in the allopurinol group and 15 in the control group). Momeni et al. [119] reported that allopurinol therapy reduces proteinuria in patients with diabetic nephropathy, but with no effect on creatinine.

It is certainly possible that the favorable results associated with allopurinol are due to effects other than its UA-lowering effects. For example, allopurinol blocks the production of reactive oxygen species, key signaling molecules in inflammatory diseases [131], which are generated during the conversion of xanthine to UA [9]. Other potential mechanisms include adenosine accumulation, which is anti-inflammatory and inhibits tumor necrosis factor- $\alpha$, nuclear factor kappa-light-chain-enhancer of activated $\mathrm{B}$ cells, and the $\mathrm{NLRP}_{3}$ inflammasome (i.e., NACHT, LRR, and PYD domain-containing protein 3) [132]. Furthermore, allopurinol treatment improves peripheral and cerebrovascular endothelial function [74,133-136]. These mechanisms may each be associated with kidney protective effects either alone or in combination.

\section{Febuxostat}

Febuxostat is a relatively new xanthine oxidase inhibitor that is safe for patients with kidney dysfunction $[137,138]$. Febuxostat is used to treat hyperuricemia in gout patients at daily doses of 40 and $80 \mathrm{mg}$ [139]. Several types of adverse effects have been associated with the use of febuxostat, some of which include cardiovascular and hepatic abnormalities that may be more common with febuxostat than with allopurinol [140].

In a randomized controlled trial of 93 patients with stage 3 and 4 CKD, febuxostat slowed a decline in eGFR compared to placebo [121]. The mean eGFR in the febuxostat group increased nonsignificantly from a baseline of $31.5 \pm 13.6$ to $34.7 \pm 18.1 \mathrm{~mL} / \mathrm{min} / 1.73 \mathrm{~m}^{2}$ at 6 months; with placebo, the mean eGFR decreased from $32.6 \pm 11.6$ to $28.2 \pm 11.5 \mathrm{~mL} / \mathrm{min} / 1.73 \mathrm{~m}^{2}$. In total, 17 of the 45 (38\%) participants in the febuxostat group showed a $10 \%$ decline in eGFR compared with 26 of 48 (54\%) in the placebo group. However, a larger randomized controlled trial failed to show a beneficial effect [122], with no significant difference in mean eGFR slopes between the febuxostat ( $0.23 \pm 5.26 \mathrm{~mL} / \mathrm{min} / 1.73 \mathrm{~m}^{2}$ per year) and placebo (-0.47 $\pm 4.48 \mathrm{~mL} / \mathrm{min} / 1.73 \mathrm{~m}^{2}$ per year) groups (difference, 0.70 ; $95 \% \mathrm{CI},-0.21$ to $1.62 ; p=0.10$ ).

Several other recent studies have compared febuxostat to placebo or allopurinol, and febuxostat retarded the decline in renal function more effectively than allopurinol $[116,123,124]$. In a Korean retrospective study, a febuxostat group had significantly lower mean serum UA levels $(5.7 \pm 1.0 \mathrm{mg} / \mathrm{dL})$ than either an allopurinol group (7.1 $\pm 1.2 \mathrm{mg} / \mathrm{dL})$ or a control group, $(8.0 \pm 0.8 \mathrm{mg} / \mathrm{dL})(p<$ 0.001 ) and maintained significantly higher mean eGFR values for 4 years. The febuxostat group also had significantly longer survival times free from renal disease progression (87.7 months; 95\% CI, 71.2 to 104.2) compared with either the allopurinol group (77.6 months; 95\% CI, 60.2 to 94.9 ) or the control group (48.7 months; $95 \% \mathrm{CI}$, 39.3 to 58.1$)(p<0.001)$ [123]. In a Chinese prospective cohort study of patients with stage 3 to ${ }_{5} \mathrm{CKD}$, the serum UA target of $<6.0 \mathrm{mg} / \mathrm{dL}$ was achieved by $96.4 \%$ of patients in the febuxostat group and by $37.5 \%$ in the allopurinol group at 6 months. The eGFR in the febuxostat group increased from 28.45 to $30.65 \mathrm{~mL} / \mathrm{min} / 1.73 \mathrm{~m}^{2}$ at 6 months, while it decreased from 28.06 to $24.39 \mathrm{~mL} /$ $\min / 1.73 \mathrm{~m}^{2}$ in the allopurinol group [116]. In another Chinese prospective cohort study of patients with stage 2 to $3 \mathrm{CKD}$, the proportion of patients showing a $\geq 10 \%$ decline in eGFR from baseline decreased by $17.9 \%$ in the febuxostat group and $34.1 \%$ in the allopurinol group $(p=0.025)[124]$. 


\section{CONCLUSIONS}

A 100-year history of basic and clinical studies supports UA being a direct risk factor for CKD. Nevertheless, controversy exists over the causal role of UA in the development or exacerbation of CKD, with conflicting results being produced in various studies. Although many nephrologists currently treat asymptomatic patients with hyperuricemia [141], there is no consensus on the appropriateness of such a treatment approach [142]. Furthermore, hypouricemia has been shown to increase the risk for deterioration of renal function, making it more difficult to set a target range for the optimal serum UA level. In the CARES trial, all-cause and cardiovascular mortality were higher in the febuxostat group than in the allopurinol group, even though patients receiving febuxostat had lower serum UA levels [140]. The higher mortality associated with this more intense UA-lowering therapy is consistent with the U-shaped association between UA and mortality proposed in some observational studies $[110,111]$. Because UA is the most abundant antioxidant in plasma, strategies to increase UA are ongoing in clinical trials of patients with neurological diseases $[143,144]$. Further research is needed to assess the safety of lowering serum UA to specific thresholds to produce safe guidelines [145]. Optimal serum UA levels should be defined at both upper and lower limits, for men and women, and in patients with and without CVD or CKD.

\section{Conflict of interest}

No potential conflict of interest relevant to this article was reported.

\section{REFERENCES}

1. Ji E, Kim YS. Prevalence of chronic kidney disease defined by using CKD-EPI equation and albumin-to-creatinine ratio in the Korean adult population. Korea $\mathrm{n} J$ Intern Med 2016;31:1120-1130.

2. Jin DC, Yun SR, Lee SW, et al. Current characteristics of dialysis therapy in Korea: 2016 registry data focusing on diabetic patients. Kidney Res Clin Pract 2018;37:20-29.

3. Levey AS, Atkins R, Coresh J, et al. Chronic kidney disease as a global public health problem: approaches and initia- tives: a position statement from Kidney Disease Improving Global Outcomes. Kidney Int 2007;72:247-259.

4. Mahomed FA. On chronic Bright's disease, and its essential symptoms. Lancet 1879;1:399-401.

5. Haig A. On uric acid and arterial tension. Br Med J 1889;1: 288-291.

6. Davis NS. The cardio-vascular and renal relations and manifestations of gout. J Am Med Assoc 1897;29:261-2.

7. Brochner-Mortensen K. 100 Gouty patients. Acta Med Scand 1941;106:81-107.

8. Talbott JH, Terplan KL. The kidney in gout. Medicine (Baltimore) 1960;39:405-467.

9. Kang DH, Chen W. Uric acid and chronic kidney disease: new understanding of an old problem. Semin Nephrol 2011;31:447-452.

10. Johnson RJ, Nakagawa T, Jalal D, Sanchez-Lozada LG, Kang DH, Ritz E. Uric acid and chronic kidney disease: which is chasing which? Nephrol Dial Transplant 2013;28:2221-2228.

11. Wakasugi M, Kazama JJ, Narita I, et al. Association between hypouricemia and reduced kidney function: a cross-sectional population-based study in Japan. Am J Nephrol 2015;41:138-146.

12. Wang S, Shu Z, Tao Q, Yu C, Zhan S, Li L. Uric acid and incident chronic kidney disease in a large health check-up population in Taiwan. Nephrology (Carlton) 2011;16:767776.

13. Fathallah-Shaykh SA, Cramer MT. Uric acid and the kidney. Pediatr Nephrol 2014;29:999-1008.

14. Maiuolo J, Oppedisano F, Gratteri S, Muscoli C, Mollace V. Regulation of uric acid metabolism and excretion. Int $\mathrm{J}$ Cardiol 2016;213:8-14.

15. Wu XW, Muzny DM, Lee CC, Caskey CT. Two independent mutational events in the loss of urate oxidase during hominoid evolution. J Mol Evol 1992;34:78-84.

16. Desideri G, Castaldo G, Lombardi A, et al. Is it time to revise the normal range of serum uric acid levels? Eur Rev Med Pharmacol Sci 2014;18:1295-1306.

17. Oda M, Satta Y, Takenaka O, Takahata N. Loss of urate oxidase activity in hominoids and its evolutionary implications. Mol Biol Evol 2002;19:640-653.

18. Bobulescu IA, Moe OW. Renal transport of uric acid: evolving concepts and uncertainties. Adv Chronic Kidney Dis 2012;19:358-371.

19. Hediger MA, Johnson RJ, Miyazaki H, Endou H. Molecular physiology of urate transport. Physiology (Bethesda) 
2005;20:125-133.

20. Preitner F, Bonny O, Laverriere A, et al. Glutg is a major regulator of urate homeostasis and its genetic inactivation induces hyperuricosuria and urate nephropathy. Proc Natl Acad Sci U S A 2009;106:15501-15506.

21. Woodward OM, Kottgen A, Coresh J, Boerwinkle E, Guggino WB, Kottgen M. Identification of a urate transporter, ABCG2, with a common functional polymorphism causing gout. Proc Natl Acad Sci U S A 2009;106:10338-10342.

22. Iharada M, Miyaji T, Fujimoto T, et al. Type 1 sodium-dependent phosphate transporter (SLC17Aı Protein) is a $\mathrm{Cl}(-)$-dependent urate exporter. J Biol Chem 2010;285:26107-26113.

23. Jutabha P, Anzai N, Kitamura K, et al. Human sodium phosphate transporter 4 (hNPT4/SLC17A 3 ) as a common renal secretory pathway for drugs and urate. J Biol Chem 2010;285:35123-35132.

24. Ichida K, Matsuo H, Takada T, et al. Decreased extra-renal urate excretion is a common cause of hyperuricemia. Nat Commun 2012;3:764.

25. Nagura M, Tamura Y, Kumagai T, Hosoyamada M, Uchida S. Uric acid metabolism of kidney and intestine in a rat model of chronic kidney disease. Nucleosides Nucleotides Nucleic Acids 2016;35:550-558.

26. Yano H, Tamura Y, Kobayashi K, Tanemoto M, Uchida S. Uric acid transporter ABCG2 is increased in the intestine of the $5 / 6$ nephrectomy rat model of chronic kidney disease. Clin Exp Nephrol 2014;18:50-55.

27. Zhu Y, Pandya BJ, Choi HK. Prevalence of gout and hyperuricemia in the US general population: the National Health and Nutrition Examination Survey 2007-2008. Arthritis Rheum 2011;63:3136-3141.

28. Lin KC, Lin HY, Chou P. Community based epidemiological study on hyperuricemia and gout in Kin-Hu, Kinmen. J Rheumatol 2000;27:1045-1050.

29. Abbasian M, Ebrahimi H, Delvarianzadeh M, Norouzi P, Fazli M. Association between serum uric acid (SUA) levels and metabolic syndrome (MetS) components in personnel of Shahroud University of Medical Sciences. Diabetes Metab Syndr 2016;10:132-136.

30. Quinones Galvan A, Natali A, Baldi S, et al. Effect of insulin on uric acid excretion in humans. Am J Physiol 1995;268(1 Pt 1):E1-E5.

31. Messerli FH, Frohlich ED, Dreslinski GR, Suarez DH, Aristimuno GG. Serum uric acid in essential hypertension: an indicator of renal vascular involvement. Ann Intern
Med 1980;93:817-821.

32. Johnson RJ, Perez-Pozo SE, Sautin YY, et al. Hypothesis: could excessive fructose intake and uric acid cause type 2 diabetes? Endocr Rev 2009;30:96-116.

33. Han T, Lan L, Qu R, et al. Temporal relationship between hyperuricemia and insulin resistance and its impact on future risk of hypertension. Hypertension 2017;70:703-711.

34. Choi HK, Atkinson K, Karlson EW, Willett W, Curhan G. Purine-rich foods, dairy and protein intake, and the risk of gout in men. N Engl J Med 2004;350:1093-1103.

35. Franco MC, Christofalo DM, Sawaya AL, Ajzen SA, Sesso R. Effects of low birth weight in 8- to 13-year-old children: implications in endothelial function and uric acid levels. Hypertension 2006;48:45-50.

36. Hummel A. Familial juvenile hyperuricemic nephropathy. Nephrol Ther 2012;8:117-125.

37. Liu Y, Goldfarb DS, El-Achkar TM, Lieske JC, Wu XR. Tamm-Horsfall protein/uromodulin deficiency elicits tubular compensatory responses leading to hypertension and hyperuricemia. Am J Physiol Renal Physiol 2018;314:F1062-F1076.

38. Olinger E, Hofmann P, Kidd K, et al. Clinical and genetic spectra of autosomal dominant tubulointerstitial kidney disease due to mutations in UMOD and MUC1. Kidney Int 2020;98:717-731.

39. Nakayama A, Nakaoka $H$, Yamamoto K, et al. GWAS of clinically defined gout and subtypes identifies multiple susceptibility loci that include urate transporter genes. Ann Rheum Dis 2017;76:869-877.

40. Ramsdell CM, Kelley WN. The clinical significance of hypouricemia. Ann Intern Med 1973;78:239-242.

41. Son CN, Kim JM, Kim SH, et al. Prevalence and possible causes of hypouricemia at a tertiary care hospital. Korean J Intern Med 2016;31:971-976.

42. Sebesta I, Stiburkova B, Krijt J. Hereditary xanthinuria is not so rare disorder of purine metabolism. Nucleosides Nucleotides Nucleic Acids 2018;37:324-328.

43. McDonagh EM, Thorn CF, Callaghan JT, Altman RB, Klein TE. PharmGKB summary: uric acid-lowering drugs pathway, pharmacodynamics. Pharmacogenet Genomics 2014;24:464-476.

44. Guttmann A, Krasnokutsky S, Pillinger MH, Berhanu A. Pegloticase in gout treatment: safety issues, latest evidence and clinical considerations. Ther Adv Drug Saf 2017;8:379-388.

45. Daskalopoulou SS, Tzovaras V, Mikhailidis DP, Elisaf M. 
Effect on serum uric acid levels of drugs prescribed for indications other than treating hyperuricaemia. Curr Pharm Des 2005;11:4161-4175.

46. Hamada T, Ichida K, Hosoyamada M, et al. Uricosuric action of losartan via the inhibition of urate transporter 1 (URAT 1) in hypertensive patients. Am J Hypertens 2008;21:1157-1162.

47. Uetake D, Ohno I, Ichida K, et al. Effect of fenofibrate on uric acid metabolism and urate transporter 1. Intern Med 2010;49:89-94.

48. Liberopoulos E, Elisaf MS. Co-trimoxazole-induced hypouricemia. Clin Nephrol 1998;49:202.

49. Ichida K, Hosoyamada M, Hisatome I, et al. Clinical and molecular analysis of patients with renal hypouricemia in Japan: influence of URAT1 gene on urinary urate excretion. J Am Soc Nephrol 2004;15:164-173.

50. Komoda F, Sekine T, Inatomi J, et al. The W258X mutation in SLC22A12 is the predominant cause of Japanese renal hypouricemia. Pediatr Nephrol 2004;19:728-733.

51. Ichida K, Hosoyamada M, Kamatani N, et al. Age and origin of the G774A mutation in SLC22A12 causing renal hypouricemia in Japanese. Clin Genet 2008;74:243-251.

52. Cheong HI, Kang JH, Lee JH, et al. Mutational analysis of idiopathic renal hypouricemia in Korea. Pediatr Nephrol 2005;20:886-890.

53. Li Z, Ding H, Chen C, Chen Y, Wang DW, Lv Y. Novel URAT1 mutations caused acute renal failure after exercise in two Chinese families with renal hypouricemia. Gene 2013;512:97-101.

54. Matsuo H, Chiba T, Nagamori S, et al. Mutations in glucose transporter 9 gene $\mathrm{SLC}_{2} \mathrm{~A}_{9}$ cause renal hypouricemia. Am J Hum Genet 2008;83:744-751.

55. Dinour D, Gray NK, Campbell S, et al. Homozygous SLC2A9 mutations cause severe renal hypouricemia. J Am Soc Nephrol 2010;21:64-72.

56. Sebesta I. Genetic disorders resulting in hyper- or hypouricemia. Adv Chronic Kidney Dis 2012;19:398-403.

57. De Coek NM. Serum urate and urate clearance in diabetes mellitus. Australas Ann Med 1965;14:205-209.

58. Herman JB, Keynan A. Hyperglycemia and uric acid. Isr J Med Sci 1969;5:1048-1052.

59. Shichiri M, Iwamoto H, Shiigai T. Diabetic renal hypouricemia. Arch Intern Med 1987;147:225-228.

6o. Erdberg A, Boner G, van Dyk DJ, Carel R. Urine uric acid excretion in patients with insulin-dependent diabetes mellitus. Nephron 1992;60:134-137.
61. Esparza Martin N, Garcia Nieto V. Hypouricemia and tubular transport of uric acid. Nefrologia 2011;31:44-50.

62. Magoula I, Tsapas G, Kountouras J, Paletas K. Cholangiocarcinoma and severe renal hypouricemia: a study of the renal mechanisms. Am J Kidney Dis 1991;18:514-519.

63. Izumi N, Sakai H, Shinohara S, Daiguji Y, Hasumura Y, Takeuchi J. Hypouricemia and renal tubular acidosis in primary biliary cirrhosis. Gastroenterol Jpn 1985;20:374379 .

64. Hisatome I, Kotake H, Ogino K, et al. Hypouricaemia with acute viral hepatitis. Br J Rheumatol 1989;28:525-527.

65. Tykarski A. Mechanism of hypouricemia in Hodgkin's disease. Isolated defect in postsecretory reabsorption of uric acid. Nephron 1988;50:217-219.

66. Mallat SG, Al Kattar S, Tanios BY, Jurjus A. Hyperuricemia, hypertension, and chronic kidney disease: an emerging association. Curr Hypertens Rep 2016;18:74.

67. Mazzali M, Hughes J, Kim YG, et al. Elevated uric acid increases blood pressure in the rat by a novel crystal-independent mechanism. Hypertension 2001;38:1101-1106.

68. Mazzali M, Kanellis J, Han L, et al. Hyperuricemia induces a primary renal arteriolopathy in rats by a blood pressure-independent mechanism. Am J Physiol Renal Physiol 2002;282:F991-F997.

69. Sanchez-Lozada LG, Tapia E, Avila-Casado C, et al. Mild hyperuricemia induces glomerular hypertension in normal rats. Am J Physiol Renal Physiol 2002;283:F1105-Fin10.

70. Kang DH, Nakagawa T, Feng L, et al. A role for uric acid in the progression of renal disease. J Am Soc Nephrol 2002;13:2888-2897.

71. Sanchez-Lozada LG, Tapia E, Santamaria J, et al. Mild hyperuricemia induces vasoconstriction and maintains glomerular hypertension in normal and remnant kidney rats. Kidney Int 2005;67:237-247.

72. Sanchez-Lozada LG, Lanaspa MA, Cristobal-Garcia M, et al. Uric acid-induced endothelial dysfunction is associated with mitochondrial alterations and decreased intracellular ATP concentrations. Nephron Exp Nephrol 2012;121:e71-e78.

73. Khosla UM, Zharikov S, Finch JL, et al. Hyperuricemia induces endothelial dysfunction. Kidney Int 2005;67:17391742.

74. Farquharson CA, Butler R, Hill A, Belch JJ, Struthers AD. Allopurinol improves endothelial dysfunction in chronic heart failure. Circulation 2002;106:221-226.

75. Butler R, Morris AD, Belch JJ, Hill A, Struthers AD. Allo- 
purinol normalizes endothelial dysfunction in type 2 diabetics with mild hypertension. Hypertension 2000;35:746751.

76. Nakagawa T, Mazzali M, Kang DH, et al. Hyperuricemia causes glomerular hypertrophy in the rat. Am J Nephrol 2003;23:2-7.

77. Ryu ES, Kim MJ, Shin HS, et al. Uric acid-induced phenotypic transition of renal tubular cells as a novel mechanism of chronic kidney disease. Am J Physiol Renal Physiol 2013;304:F471-F480.

78. Ames BN, Cathcart R, Schwiers E, Hochstein P. Uric acid provides an antioxidant defense in humans against oxidant- and radical-caused aging and cancer: a hypothesis. Proc Natl Acad Sci U S A 1981;78:6858-6862.

79. Davies KJ, Sevanian A, Muakkassah-Kelly SF, Hochstein P. Uric acid-iron ion complexes: a new aspect of the antioxidant functions of uric acid. Biochem J 1986;235:747-754.

8o. Simic MG, Jovanovic SV. Antioxidation mechanisms of uric acid. J Am Chem Soc 1989;111:5778-5782.

81. Ostendorf BN, Blau O, Uharek L, Blau IW, Penack O. Association between low uric acid levels and acute graftversus-host disease. Ann Hematol 2015;94:139-144.

82. Fang P, Li X, Luo JJ, Wang H, Yang XF. A double-edged sword: uric acid and neurological disorders. Brain Disord Ther 2013;2:109.

83. Ishikawa I. Acute renal failure with severe loin pain and patchy renal ischemia after anaerobic exercise in patients with or without renal hypouricemia. Nephron 2002;91:559-570.

84. Kikuchi Y, Koga H, Yasutomo Y, et al. Patients with renal hypouricemia with exercise-induced acute renal failure and chronic renal dysfunction. Clin Nephrol 2000;53:467472.

85. Ohta T, Sakano T, Igarashi T, Itami N, Ogawa T; ARF Associated with Renal Hypouricemia Research Group. Exercise-induced acute renal failure associated with renal hypouricaemia: results of a questionnaire-based survey in Japan. Nephrol Dial Transplant 2004;19:1447-1453.

86. Coca SG, Singanamala S, Parikh CR. Chronic kidney disease after acute kidney injury: a systematic review and meta-analysis. Kidney Int 2012;81:442-448.

87. Bordier L, Blanchard A, Sarret D, Herody M, Nedelec G, Duvic C. Hypouricemia, an old subject and new concepts. Presse Med 2004;33:555-563.

88. Rosolowsky ET, Ficociello LH, Maselli NJ, et al. High-normal serum uric acid is associated with impaired glomer- ular filtration rate in nonproteinuric patients with type 1 diabetes. Clin J Am Soc Nephrol 2008;3:706-713.

89. Zoppini G, Targher G, Chonchol M, et al. Serum uric acid levels and incident chronic kidney disease in patients with type 2 diabetes and preserved kidney function. Diabetes Care 2012;35:99-104.

90. Domrongkitchaiporn S, Sritara P, Kitiyakara C, et al. Risk factors for development of decreased kidney function in a southeast Asian population: a 12-year cohort study. J Am Soc Nephrol 2005;16:791-799.

91. Chonchol M, Shlipak MG, Katz R, et al. Relationship of uric acid with progression of kidney disease. Am J Kidney Dis 2007;50:239-247.

92. Obermayr RP, Temml C, Gutjahr G, Knechtelsdorfer M, Oberbauer R, Klauser-Braun R. Elevated uric acid increases the risk for kidney disease. J Am Soc Nephrol 2008;19:2407-2413.

93. Hsu CY, Iribarren C, McCulloch CE, Darbinian J, Go AS. Risk factors for end-stage renal disease: 25-year follow-up. Arch Intern Med 2009;169:342-350.

94. Bellomo G, Venanzi S, Verdura C, Saronio P, Esposito A, Timio M. Association of uric acid with change in kidney function in healthy normotensive individuals. Am J Kidney Dis 2010;56:264-272.

95. Sonoda H, Takase H, Dohi Y, Kimura G. Uric acid levels predict future development of chronic kidney disease. Am J Nephrol 2011;33:352-357.

96. Uchida S, Chang WX, Ota T, et al. Targeting uric acid and the inhibition of progression to end-stage renal disease: a propensity score analysis. PLoS One 2015;10:e0145506.

97. Rodenbach KE, Schneider MF, Furth SL, et al. Hyperuricemia and progression of CKD in children and adolescents: the Chronic Kidney Disease in Children (CKiD) cohort study. Am J Kidney Dis 2015;66:984-992.

98. Oh TR, Choi HS, Kim CS, et al. Hyperuricemia has increased the risk of progression of chronic kidney disease: propensity score matching analysis from the KNOWCKD study. Sci Rep 2019;9:6681.

99. Iseki K, Ikemiya Y, Inoue T, Iseki C, Kinjo K, Takishita S. Significance of hyperuricemia as a risk factor for developing ESRD in a screened cohort. Am J Kidney Dis 2004;44:642-650.

100. Li L, Yang C, Zhao Y, Zeng X, Liu F, Fu P. Is hyperuricemia an independent risk factor for new-onset chronic kidney disease? A systematic review and meta-analysis based on observational cohort studies. BMC Nephrol 2014;15:122. 
101. Chien KL, Lin HJ, Lee BC, Hsu HC, Lee YT, Chen MF. A prediction model for the risk of incident chronic kidney disease. Am J Med 2010;123:836-846.

102. Lee C, Yun HR, Joo YS, et al. Framingham risk score and risk of incident chronic kidney disease: a community-based prospective cohort study. Kidney Res Clin Pract 2019;38:49-59.

103. Jhee JH, Joo YS, Han SH, Yoo TH, Kang SW, Park JT. High muscle-to-fat ratio is associated with lower risk of chronic kidney disease development. J Cachexia Sarcopenia Muscle 2020;11:726-734.

104. Kim JK, Kim SG, Oh JE, et al. Impact of sarcopenia on long-term mortality and cardiovascular events in patients undergoing hemodialysis. Korean J Intern Med 2019;34:599-607.

105. Lamacchia O, Nicastro V, Camarchio D, et al. Para- and perirenal fat thickness is an independent predictor of chronic kidney disease, increased renal resistance index and hyperuricaemia in type-2 diabetic patients. Nephrol Dial Transplant 2011;26:892-898.

106. Kim Y, Park CW. Can management of the components of metabolic syndrome modify the course of chronic kidney disease? Kidney Res Clin Pract 2020;39:118-120.

107. Sturm G, Kollerits B, Neyer U, Ritz E, Kronenberg F; MMKD Study Group. Uric acid as a risk factor for progression of non-diabetic chronic kidney disease?: the Mild to Moderate Kidney Disease (MMKD) study. Exp Gerontol 2008;43:347-352.

108. Madero M, Sarnak MJ, Wang X, et al. Uric acid and longterm outcomes in CKD. Am J Kidney Dis 2009;53:796-803.

109. Srivastava A, Kaze AD, McMullan CJ, Isakova T, Waikar SS. Uric acid and the risks of kidney failure and death in individuals with CKD. Am J Kidney Dis 2018;71:362-370.

110. Odden MC, Amadu AR, Smit E, Lo L, Peralta CA. Uric acid levels, kidney function, and cardiovascular mortality in US adults: National Health and Nutrition Examination Survey (NHANES) 1988-1994 and 1999-2002. Am J Kidney Dis 2014;64:550-557.

111. Tseng WC, Chen YT, Ou SM, Shih CJ, Tarng DC; Taiwan Geriatric Kidney Disease (TGKD) Research Group. U-shaped association between serum uric acid levels with cardiovascular and all-cause mortality in the elderly: the role of malnourishment. J Am Heart Assoc 2018;7:e007523.

112. Kanda E, Muneyuki T, Kanno Y, Suwa K, Nakajima K. Uric acid level has a U-shaped association with loss of kidney function in healthy people: a prospective cohort study.
PLoS One 2015;10:e0118031.

113. Kuwabara M, Niwa K, Ohtahara A, et al. Prevalence and complications of hypouricemia in a general population: a large-scale cross-sectional study in Japan. PLoS One 2017;12:e0176055.

114. Mun KH, Yu GI, Choi BY, Kim MK, Shin MH, Shin DH. Effect of uric acid on the development of chronic kidney disease: the Korean multi-rural communities cohort study. J Prev Med Public Health 2018;51:248-256.

115. Jin DC. Analysis of mortality risk from Korean hemodialysis registry data 2017. Kidney Res Clin Pract 2019;38:169175 .

116. Liu X, Zhai T, Ma R, Luo C, Wang H, Liu L. Effects of uric acid-lowering therapy on the progression of chronic kidney disease: a systematic review and meta-analysis. Ren Fail 2018;40:289-297.

117. Siu YP, Leung KT, Tong MK, Kwan TH. Use of allopurinol in slowing the progression of renal disease through its ability to lower serum uric acid level. Am J Kidney Dis 2006;47:51-59.

118. Goicoechea M, de Vinuesa SG, Verdalles U, et al. Effect of allopurinol in chronic kidney disease progression and cardiovascular risk. Clin J Am Soc Nephrol 2010;5:13881393 .

119. Momeni A, Shahidi S, Seirafian S, Taheri S, Kheiri S. Effect of allopurinol in decreasing proteinuria in type 2 diabetic patients. Iran J Kidney Dis 2010;4:128-132.

120. Shi Y, Chen W, Jalal D, et al. Clinical outcome of hyperuricemia in IgA nephropathy: a retrospective cohort study and randomized controlled trial. Kidney Blood Press Res 2012;35:153-160.

121. Sircar D, Chatterjee S, Waikhom R, et al. Efficacy of febuxostat for slowing the GFR decline in patients with CKD and asymptomatic hyperuricemia: a 6-month, double-blind, randomized, placebo-controlled trial. Am J Kidney Dis 2015;66:945-950.

122. Kimura K, Hosoya T, Uchida S, et al. Febuxostat therapy for patients with stage $3 \mathrm{CKD}$ and asymptomatic hyperuricemia: a randomized trial. Am J Kidney Dis 2018;72:798-810.

123. Lee JW, Lee KH. Comparison of renoprotective effects of febuxostat and allopurinol in hyperuricemic patients with chronic kidney disease. Int Urol Nephrol 2019;51:467473.

124. Zhang X, Wan D, Yang G, Peng Q, Wang X. Febuxostat is superior to allopurinol in delaying the progression of 
renal impairment in patients with chronic kidney disease and hyperuricemia. Int Urol Nephrol 2019;51:2273-2283.

125. Hande KR, Noone RM, Stone WJ. Severe allopurinol toxicity. Description and guidelines for prevention in patients with renal insufficiency. Am J Med 1984;76:47-56.

126. Khanna D, Fitzgerald JD, Khanna PP, et al. 2012 American College of Rheumatology guidelines for management of gout. Part 1: systematic nonpharmacologic and pharmacologic therapeutic approaches to hyperuricemia. Arthritis Care Res (Hoboken) 2012;64:1431-1446.

127. Stamp LK, Taylor WJ, Jones PB, et al. Starting dose is a risk factor for allopurinol hypersensitivity syndrome: a proposed safe starting dose of allopurinol. Arthritis Rheum 2012;64:2529-2236.

128. Wallace SL, Singer JZ. Therapy in gout. Rheum Dis Clin North Am 1988;14:441-457.

129. Halevy S, Ghislain PD, Mockenhaupt M, et al. Allopurinol is the most common cause of Stevens-Johnson syndrome and toxic epidermal necrolysis in Europe and Israel. J Am Acad Dermatol 2008;58:25-32.

130. Kanbay M, Ozkara A, Selcoki Y, et al. Effect of treatment of hyperuricemia with allopurinol on blood pressure, creatinine clearence, and proteinuria in patients with normal renal functions. Int Urol Nephrol 2007;39:1227-1233.

131. Mittal M, Siddiqui MR, Tran K, Reddy SP, Malik AB. Reactive oxygen species in inflammation and tissue injury. Antioxid Redox Signal 2014;20:1126-1167.

132. Schlesinger N, Brunetti L. Beyond urate lowering: analgesic and anti-inflammatory properties of allopurinol. Semin Arthritis Rheum 2020;50:444-450.

133. Doehner W, Schoene N, Rauchhaus M, et al. Effects of xanthine oxidase inhibition with allopurinol on endothelial function and peripheral blood flow in hyperuricemic patients with chronic heart failure: results from 2 placebo-controlled studies. Circulation 2002;105:2619-2624.

134. Khan F, George J, Wong K, McSwiggan S, Struthers AD, Belch JJ. Allopurinol treatment reduces arterial wave reflection in stroke survivors. Cardiovasc Ther 2008;26:247-
252.

135. George J, Struthers AD. The role of urate and xanthine oxidase inhibitors in cardiovascular disease. Cardiovasc Ther 2008;26:59-64.

136. Mercuro G, Vitale C, Cerquetani E, et al. Effect of hyperuricemia upon endothelial function in patients at increased cardiovascular risk. Am J Cardiol 2004;94:932-935.

137. Shibagaki Y, Ohno I, Hosoya T, Kimura K. Safety, efficacy and renal effect of febuxostat in patients with moderate-to-severe kidney dysfunction. Hypertens Res 2014;37:919-925.

138. Kim SH, Lee SY, Kim JM, Son CN. Renal safety and urate-lowering efficacy of febuxostat in gout patients with stage 4-5 chronic kidney disease not yet on dialysis. Korean J Intern Med 2020;35:998-1003.

139. Avena-Woods C, Hilas O. Febuxostat (Uloric), a new treatment option for gout. Pharmacy and Ther 2010;35:82.

140. White WB, Saag KG, Becker MA, et al. Cardiovascular safety of febuxostat or allopurinol in patients with gout. N Engl J Med 2018;378:1200-1210.

141. Cha RH, Kim SH, Bae EH, et al. Physicians' perceptions of asymptomatic hyperuricemia in patients with chronic kidney disease: a questionnaire survey. Kidney Res Clin Pract 2019;38:373-381.

142. Shin DH. To treat or not to treat asymptomatic hyperuricemia in chronic kidney disease. Kidney Res Clin Pract 2019;38:257-259.

143. Chamorro A, Amaro S, Castellanos M, et al. Safety and efficacy of uric acid in patients with acute stroke (URICO-ICTUS): a randomised, double-blind phase $2 \mathrm{~b} / 3$ trial. Lancet Neurol 2014;13:453-460.

144. Llull L, Laredo C, Renu A, et al. Uric acid therapy improves clinical outcome in women with acute ischemic stroke. Stroke 2015;46:2162-2167.

145. Perez-Gomez MV, Bartsch LA, Castillo-Rodriguez E, Fernandez-Prado R, Kanbay M, Ortiz A. Potential dangers of serum urate-lowering therapy. Am J Med 2019;132:457-467. 